\title{
THE LIGHT FROM GALILEE
}

The Narrative Function of Isaiah 8:23-9:6 in John 8:12

\author{
KAI AKAGI \\ University of St Andrews
}

\begin{abstract}
Application of criteria for identifying scriptural reuse demonstrates that John 8:12 is a specific allusion to Isa 9:1. Affirming the often overlooked proposal that the allusion answers the objection to Jesus in 7:52, this paper suggests the allusion serves a multi-layered narrative function. It demonstrates that Jesus' opponents are ignorant of the portion of Isaiah to which he alludes, undermines them for their failure to know the Scriptures that testify on

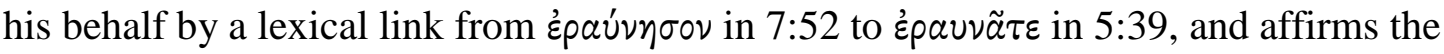
messianic identity of Jesus in accordance with the purpose of the book.
\end{abstract}

Key Words: John; Isaiah; light; Galilee; allusion; intertextuality

\section{Introduction}

Interpreters have suggested various explanations of Jesus' self-identification as the light of the world in John 8:12. Yet, despite the features of the verse suggesting a close link with what precedes, many have given little account for how 8:12 functions within the flow of thought in Chapters 7-8 and the narrative of the book. I will argue for the often overlooked proposal that 8:12 specifically alludes to Isa 8:23-9:6 (LXX 9:1-7) to refute the objection to Jesus in 7:52. I will further argue that, by making this allusion, 8:12 serves a multi-layered narrative function to undermine Jesus' opponents by revealing their failure to know the Scriptures and to affirm Jesus' identity as Messiah.

\section{Previous Interpretations of John 8:12}

John 8:12 most obviously continues the light motif characterizing the first half of the book. Commentators have offered six primary interpretations of the verse that view it as additionally making a reference external to John. Many have suggested associations, or at 
least close parallels, with light and darkness dualism in Qumran literature ${ }^{1}$ or have suggested that it recalls simhat beit hasho'eva during the Feast of Tabernacles as described in $m$. Sukkah 5:1-5 and t. Sukkah 4:1-9. ${ }^{2}$ Although less common in recent scholarship, some have compared light and darkness imagery in John, including in 8:12, to gnostic or early gnostic dualism. ${ }^{3}$ Others associate Jesus' statement with the lights of Hanukkah, understanding 10:22 to designate the temporal setting of 8:12 through the end of Chapter $10 .{ }^{4}$ Still others note the association of light with Torah, primarily in rabbinic literature but also earlier, as in 2 Bar. 54:13-14. ${ }^{5}$ Finally, many recognize light-darkness imagery in the OT, and sometimes also elsewhere in early Christianity, and view 8:12 as using a common image or as alluding

\footnotetext{
${ }^{1}$ E.g. Raymond E. Brown, The Gospel according to John (i-xii) (AB; Garden City, N.Y.: Doubleday \& Company, 1966) 340. The association of John 8:12 with Qumran literature has come under significant fire. Early on, C.K. Barrett considered the suggested parallel questionable since John and the Qumran literature lack unique corresponding elements and light-darkness imagery also appears in the OT: "Whether however these passages contribute anything to the understanding of the Fourth Gospel is doubtful; even [1QS] 3.7, which contains the expression 'light of life' (אור החיים), betrays rather an affiliation with the Old Testament which John shares, and the contrast in 3.20f. (cf. 4.11) between light and darkness is hardly more dualistic than any moral philosopher who distinguishes between good and evil and is prepared to use metaphor in his exposition. John and the Qumran author share the conviction that right and wrong are and remain ultimately distinct; they have little more than this, and their acquaintance with the Old Testament, in common," C.K. Barrett, The Gospel according to St John: An Introduction with Commentary and Notes on the Greek Text (2nd ed.; London: SPCK, 1978) 337. More recently, Richard Bauckham has pointed out several differences in the way in which the imagery of light and darkness is used, and Jörg Frey has thoroughly argued against associating this and other dualistic language in John with Qumran literature. See Richard Bauckham, "The Qumran Community and the Gospel of John," in The Testimony of the Beloved Disciple: Narrative, History, and Theology in the Gospel of John (Grand Rapids: Baker Academic, 2007) 125-136, and Jörg Frey, "Licht aus den Höhlen? Der ,johanneische Dualismus“ und die Texte von Qumran," in Kontexte des Johannesevangeliums: Das vierte Evangelium in religions- und traditionsgeschichtlicher Perspektive (ed. Jörg Frey and Udo Schnelle; WUNT 175; Tübingen: Mohr Siebeck, 2004) 117-203.
}

${ }^{2}$ E.g. Barrett, The Gospel according to St John, 335 (Barrett views the background to combine allusion to this ceremony with other ideas from within and outside Judaism); George R. Beasley-Murray, John (WBC 36; Waco, Tex.: Word Books, 1987) 127; Andreas J. Köstenberger, John (BECNT; Grand Rapids: Baker Academic, 2004) 253.

${ }^{3}$ See the discussion and references in Enno Edzard Popkes, “„Ich bin das Licht” - Erwägungen zur Verhältnisbestimmung des Thomasevangeliums und der johanneischen Schriften anhand der Lichtmetaphorik," in Frey and Schnelle, Kontexte des Johannesevangeliums, 641-674. Popkes himself considers John's use of the light metaphor "gnosisnah" (664).

${ }^{4}$ John C. Poirier, "Hanukkah in the Narrative Chronology of the Fourth Gospel," NTS 54 (2008) 465478; Ben Witherington III, John's Wisdom: A Commentary on the Fourth Gospel (Cambridge: Lutterworth Press, 1995) 173.

${ }^{5}$ See, e.g., Craig R. Koester, Symbolism in the Fourth Gospel: Meaning, Mystery, Community (Minneapolis: Fortress Press, 1995) 128-129, 136 with references; only 136 concerns 8:12 specifically. 
generally to various OT passages. ${ }^{6}$ These views are not all mutually exclusive, and some interpreters view 8:12 as having multiple references.

None of these explanations, however, accounts for the placement of John 8:12 at the particular point where it appears. Certainly, associating it with simhat beit hasho 'eva offers a reason for its presence in Chapters 7 and 8 and perhaps particularly after mentioning the last day of the feast in 7:37. However, it does not explain why it occurs at 8:12 rather than closer to $7: 37$, and the association suffers from additional weaknesses. The description of simhat beit hasho'eva in $m$. Sukkah 5:1-5 and t. Sukkah 4:1-9, although mentioning lamps and torches used during the ceremony, does not place particular emphasis on them or give them any symbolic significance. ${ }^{7}$ Furthermore, although John's many allusions to the OT seem to reflect the expectation that readers would be familiar with the Jewish scriptures, an audience that needed Jew-Samaritan tensions explained in 4:9 and might not have known that the water jars in 2:6 were for Jewish purification would not likely have picked up on a reference to this rite. The connection may have evoked additional significance in the minds of readers familiar with the ceremony, but it does not likely represent the primary significance of the verse. ${ }^{8}$

\section{John 8:12 as Allusion to Isa 8:23-9:6}

Could John 8:12, however, primarily combine an allusion to a specific OT text with the book's light motif, and do its features and textual context support reading it as such? ${ }^{9}$

\footnotetext{
${ }^{6}$ Note, e.g., Thomas L. Brodie, The Gospel according to John: A Literary and Theological Commentary (New York: Oxford University Press, 1993) 323, who combines use of light imagery in the OT and Qumran literature as background for John 8:12, and the many references in Beasley-Murray, John, 127-128.

${ }^{7}$ Whether the description reflects actual practice when the temple was standing is also uncertain. See the qualifications and discussion of the rite in Jeffrey L. Rubenstein, The History of Sukkot in the Second Temple and Rabbinic Periods (BJS 302; Atlanta: Scholars Press, 1995), 103-106, 131-152.

${ }^{8}$ As Richard Bauckham, who is more positive concerning the likelihood of an allusion to the rite, observes, "Readers with this knowledge would certainly benefit from it in their reading of these chapters, but the chapters are nevertheless quite intelligible to readers who lack this knowledge," Bauckham, The Testimony of the Beloved Disciple, 122.

${ }^{9}$ For a consideration of a similar combination in a metaphor from John from a cognitive semantics perspective, see Jesper Tang Nielsen, "The Lamb of God: The Cognitive Structure of a Johannine Metaphor," in Imagery in the Gospel of John: Terms, Forms, Themes, and Theology of Johannine Figurative Language (ed.
} 
Although obscured by the later insertion of the Pericope Adulterae, 8:12 continues the dispute concerning Jesus at the end of John $7 .{ }^{10}$ As also suggested by a few others who have often been overlooked, I propose that 8:12 deliberately recalls the language of Isa 9:1, הָָָָ

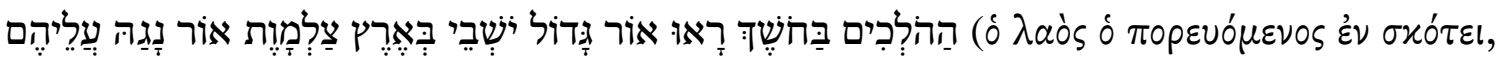

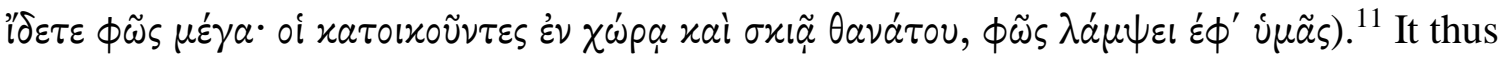
answers the objections to Jesus' Galilean origin by the Pharisees in the immediately preceding verse (7:52) and earlier by some in the crowd in 7:41. This allusion draws on the

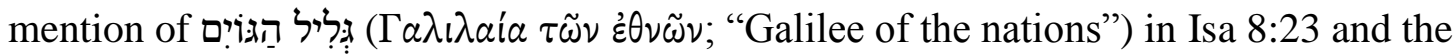
prediction of the birth of a Davidic ruler as the passage continues through Isa 9:6 to show that Jesus, as the Messiah, not only can, but must be from Galilee. Barnabas Lindars offers the same argument, although with slight hesitation. ${ }^{12}$ Philip Comfort, in a three-page article, and Craig R. Koester also make this proposal, apparently independently and without any additional supporting arguments. ${ }^{13}$ In his commentary on John, Hartwig Thyen, although associating 8:12 particularly with Isa 42:6 in an earlier article, ${ }^{14}$ follows Lindars, adding that

Jörg Frey, Jan G. van der Watt, and Ruben Zimmermann in collaboration with Gabi Kern; WUNT 200; Tübingen: Mohr Siebeck, 2006) 217-256. Thanks to Grant Macaskill for pointing me to this article.

${ }^{10}$ For a survey of research on the Pericope Adulterae, see Chris Keith, "Recent and Previous Research on the Pericope Adulterae (John 7.53-8.11)," CBR 6 (2008) 377-404.

${ }^{11}$ In the NRSV, "The people who walked in darkness have seen a great light; those who lived in a land of deep darkness - on them light has shined." English translations of biblical texts throughout are taken from the NRSV. The text of Greek Isaiah is from Joseph Ziegler, Isaias, vol. 14 of Septuaginta: Vetus Testamentum Graecum (Göttingen, Germany: Vandenhoeck \& Ruprecht, 1983). Note that the Greek of Isaiah varies in its

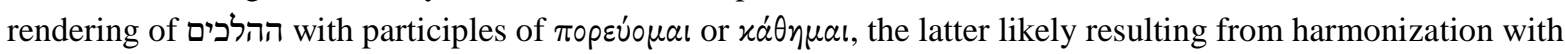
Matt 4:16, as noted to me by one of the editors of NovT.

${ }^{12}$ Barnabas Lindars, The Gospel of John (NCB; London: Oliphants, 1972) 302-303, 315-316.

${ }^{13}$ Philip Comfort, "The Pericope of the Adulteress," BT 40 (1989) 145-147; Koester, Symbolism in the Fourth Gospel, 138.

14 Thyen, "Ich bin das Licht der Welt: Das Ich- und Ich-Bin-Sagen Jesu im Johannesevangelium," in Jahrbuch für Antike und Christentum (Jahrgang 35:1992; Münster: Aschendorffsche Verlagsbuchhandlung, 1993) 38, although see his comparison of Jesus' words to Isa 42:16 on 25. 
8:12 makes a dual allusion to Isa 9:1 (9:2) and Isa 42:6. ${ }^{15}$ Stephen Motyer and Andreas J.

Köstenberger also briefly mention this view non-committedly, Motyer by citing Lindars and noting the presence of oũv in 8:12, and Köstenberger by citing Motyer. ${ }^{16}$

Craig Keener, who, unlike many other writers, notes this proposal, objects, "But light is too familiar a biblical image to limit ourselves to this one source when John 8:12 fails to give clearer clues that point to it." ${ }^{\prime 17}$ Clearer clues do emerge, however, through careful reading with criteria for recognizing use of a previous text in mind. The suggested allusion may be analyzed using William Tooman's principles for determining "deliberate literary borrowing": uniqueness, distinctiveness, multiplicity, thematic correspondence, and inversion. ${ }^{18}$

Imagery of light and darkness is by no means distinctive or unique, as Keener's objection notes. However, Jesus' statement after his self-predication in 8:12 that $\delta$ áxo $\lambda \circ v \theta \tilde{\omega} v$

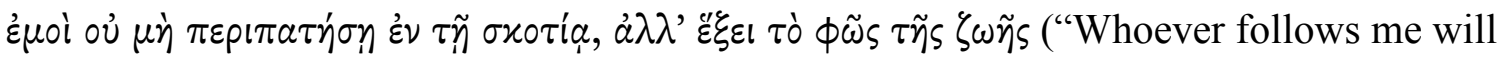
never walk in darkness but will have the light of life") uniquely corresponds to the passage from Isaiah. Isa 9:1 is the only verse in the OT containing the verb הלך and the noun חשֶֶׁ that negates people walking in darkness due to the presence of a light. ${ }^{19}$ It is the only one of four

15 Thyen, Das Johannesevangelium, 422-423.

${ }^{16}$ Stephen Motyer, Your Father the Devil? A New Approach to John and 'the Jews', Paternoster Biblical and Theological Studies (Carlisle: Paternoster Press, 1997) 155-156; Köstenberger, John, $253 n 4$. $1: 739$.

${ }^{17}$ Craig Keener, The Gospel of John: A Commentary (2 vols.; Peabody, Mass.: Hendrickson, 2003)

${ }^{18}$ William A. Tooman, Gog of Magog: Reuse of Scripture and Compositional Technique in Ezekiel 3839 (FAT 2/52; Tübingen: Mohr Siebeck, 2011) 27-31. While Tooman's focus on recognizing implicit scriptural reuse, particularly in Ezekiel, differs in some respects from the identification of an allusion to Isa in a NT gospel text, his principles are nevertheless useful for identification.

${ }^{19}$ All statistical and distribution information was obtained through searches in the Groves-Wheeler Westminster Morphology and Lemma Database 4.14 (Chestnut Hill 2010) and the BibleWorks LXX/OG Morphology and Lemma Database (Norfolk 2001) using BibleWorks 9 (Norfolk 2013). While the LXX is a scholarly construct and discussion of the occurrence of words in the Hebrew and Greek versions of the OT 


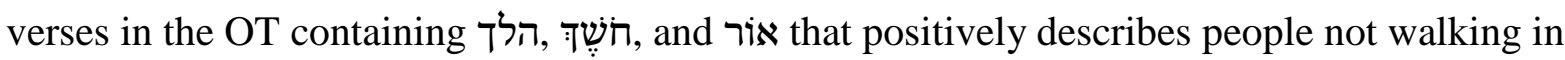
darkness (Job 29:3, although also positive, speaks about walking in darkness by God's light rather than not walking in darkness). ${ }^{20}$ Turning to another word for light, Isa 9:1 is the only

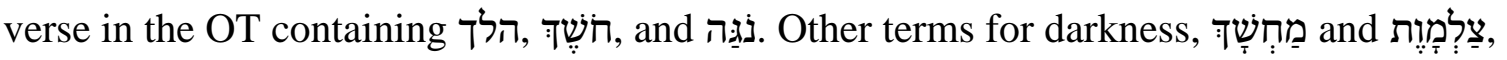
only occur with הלך In Isa 42:16 and in Job 10:21, Ps 23:4, Isa 9:1, and Jer 2:6, respectively. However, in Isa 42:16, הלך occurs in the Hiphil to speak of God bringing the blind in a way

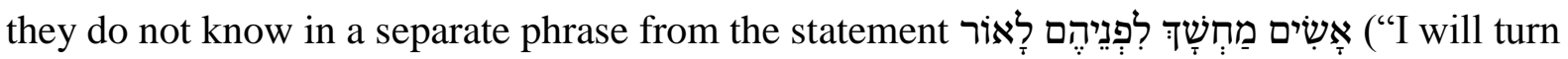
the darkness before them into light") later in the verse, and Job 10:21, Ps 23:4, and Jer 2:6 make no mention of light, leaving Isa 9:1 alone. הָפֵַלָ and the Piel of ocur together in Isa 59:9, which appears to draw from the imagery of earlier parts of Isa, such as 9:1. However, here Israel, suffering as the result of its sin, desires justice and light but finds none, creating a related but different picture from Isa 9:1 and, indeed, from John 8:12. Searches for

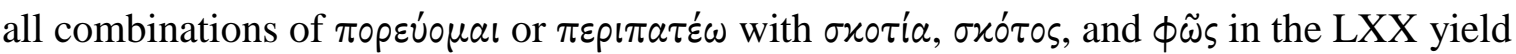
the same results. Mention of Galilee by name in Isa 8:23 and John 7:52 also strengthens the unique correspondence between the two passages.

The principle of multiplicity increases the likelihood of this allusion when considering either John's use of Isaiah or the early interpretation of Isa 8:23-9:6. Marked quotations of Isaiah appear in 1:23 (Isa 40:3), 6:45 (Isa 54:13), 12:38 (Isa 53:1), and 12:40 (Isa 6:10). Many acknowledge that the programmatic "I am" statements in John derive at least in part

would ideally consider textual variation, in the absence of a searchable database including these variants I was not able to perform more exhaustive searches that would take textual variation into account. than in light.

${ }^{20}$ The other two verses are Isa 59:9 and Lam 3:2, both of which speak of walking in darkness rather 


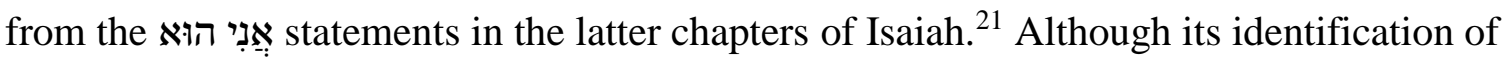
citations and allusions is imprecise and I would disagree with its analysis at points, the listing of over forty citations and allusions to Isaiah in John in NA ${ }^{28}$ highlights John's significant use of Isaiah. ${ }^{22}$ Andrew Lincoln has also drawn attention to the use of Isaianic language and imagery throughout John in discussion of the gospel's lawsuit motif. ${ }^{23}$

The attested messianic interpretation of Isa 8:23-9:6 outside of John also strengthens the likelihood that 8:12 may allude to it. Matthew 4:15-16 and Luke 1:79 quote from this passage of Isaiah, applying it to Jesus. Luke 1:32-33 similarly alludes to Isa 9:6, and Richard Bauckham has raised the possibility of the thought of Isa 9:6 behind John $12: 34 .{ }^{24}$ Outside of Christian literature, messianic interpretation of Isa 9:6 is attested in 2 Bar. 73:1.

I will not discuss thematic correspondence here since the narrative function I propose for the allusion will relate the themes of the two texts, and John 8:12 does not exhibit inversion. However, the sequence of elements in Isa 8:23-9:1 and John 7:52-8:12 is identical. Without the self-predicating statement in 8:12, both contain the elements Galilee, walking, darkness, and light in identical order.

Despite these links suggesting a deliberate allusion, many writers do not mention the possibility of Isa 9 as any kind of background to John 8:12 at all, even in combination with other OT light-darkness imagery. Such writers include Walter Bauer, ${ }^{25}$ George R. Beasley-

${ }^{21}$ Andrew T. Lincoln, Truth on Trial: The Lawsuit Motif in the Fourth Gospel (Peabody, Mass.: Hendrickson, 2000) 44-45; Grant Macaskill, Union with Christ in the New Testament (Oxford: Oxford University Press, 2013) 257-261.

${ }^{22}$ Barbara Aland et al., eds., Novum Testamentum Graece (28th rev. ed.; Stuttgart: Deutsche Bibelgesellschaft, 2012) 857-861.

${ }^{23}$ Lincoln, Truth on Trial, 38-54.

${ }^{24}$ Richard Bauckham, "Jewish Messianism according to the Gospel of John," in The Testimony of the Beloved Disciple, 236.

${ }^{25}$ Bauer, Johannes, 87. 
Murray, ${ }^{26}$ J.H. Bernard,${ }^{27}$ Thomas L. Brodie,${ }^{28}$ Raymond E. Brown, ${ }^{29}$ F.F. Bruce,${ }^{30}$ Rudolf

Bultmann, ${ }^{31}$ Ulrich Busse, ${ }^{32}$ D.A. Carson, ${ }^{33}$ C.H. Dodd,${ }^{34}$ R.H. Lightfoot,${ }^{35}$ Francis J.

Moloney, ${ }^{36}$ J. Ramsey Michaels, ${ }^{37}$ Leon Morris, ${ }^{38}$ J.N. Sanders and B.A. Mastin, ${ }^{39}$ Udo

${ }^{26}$ Beasley-Murray, John, 126-129.

27 J.H. Bernard, A Critical and Exegetical Commentary on the Gospel according to St. John (ed. A.H. McNeile; 2 vols.; ICC; Edinburgh: T. \& T. Clark, 1928) 291-293.

${ }^{28}$ Brodie, The Gospel according to John: A Literary and Theological Commentary, 323-324.

${ }^{29}$ Raymond E. Brown, The Gospel according to John (i-xii) (AB; Garden City, N.Y.: Doubleday \& Company, 1966) 340, 343-344.

${ }^{30}$ F.F. Bruce, The Gospel of John: Introduction, Exposition and Notes (Basingstoke: Pickering \& Inglis: 1983) 188.

${ }^{31}$ Rudolf Bultmann, Das Evangelium des Johannes (18th ed., KEK, 2nd division; Göttingen: Vandenhoeck \& Ruprecht, 1964) 260-261.

${ }^{32}$ Ulrich Busse, Das Johannesevangelium: Bildlichkeit, Diskurs und Ritual (BETL 162; Leuven: Leuven University Press, 2002) 164.

${ }^{33}$ D.A. Carson, The Gospel according to John (Leicester: Inter-Varsity Press, 1991) 337-339.

${ }^{34}$ C.H. Dodd, Historical Tradition in the Fourth Gospel (Cambridge: Cambridge University Press, 1963), references to $8: 12$ on $54,130,185,317,375,377$.

${ }^{35}$ R.H. Lightfoot, St. John's Gospel: A Commentary (ed. C.F. Evans; 1956; repr., Oxford: Clarendon Press, 1957) 189-190.

${ }^{36}$ Francis J. Moloney, The Gospel of John (ed. Daniel J. Harrington; SP 4; Collegeville, Minn.: Liturgical Press, 1998) 266-268. Moloney interprets Jesus' statement as associating himself with the Temple as the light of Jerusalem and the Torah as light, citing $m$. Sukkah 5:3; Wis 18:4; Ps 119:105; Prov 6:23; Sir 24:27; Bar 4:2; T. Levi 14:4; and Exod. Rab. 36:3, none of which parallel John 8:12 as closely as Isa 9.

${ }^{37}$ Michaels, The Gospel of John, 476-479. Michaels does not mention any parallels outside of John.

${ }^{38}$ Morris, The Gospel according to John, 436-439. This is despite his statement that "it must always be borne in mind that light is a common theme in both Old and New Testaments, so that it is not necessary for us to find the source of Jesus' great saying in any non-biblical place" (437).

39 J.N. Sanders and B.A. Mastin, A Commentary on the Gospel according to St John (BNTC; London: Adam \& Charles Black, 1968) 218-219. 
Schnelle, ${ }^{40}$ Folker Siegert, ${ }^{41}$ Herman C. Waetjen, ${ }^{42}$ Brooke Foss Westcott, ${ }^{43}$ and Ben

Witherington. ${ }^{44}$ However, the allusion's explanatory power for the placement of 8:12 where it appears in John and the narrative function it would play in the book further strengthen the likelihood of the allusion, and it is to this that we now turn.

\section{The Function of John 8:12 as Allusion}

As mentioned above, the allusion to Isa 8:23-9:6 in John 8:12 serves to answer the

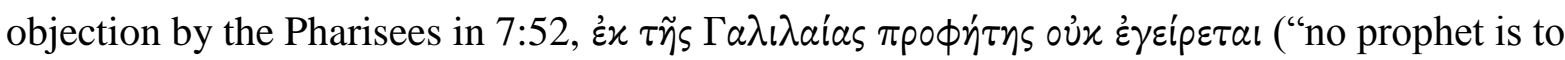
arise from Galilee"). In this final section, I will consider how this link accounts for additional features of 8:12 otherwise unexplained and will further explore how this response functions to undermine Jesus' opponents according to some of the book's larger themes.

Besides the proposed allusion, other features of John 8:12 suggest a link with what

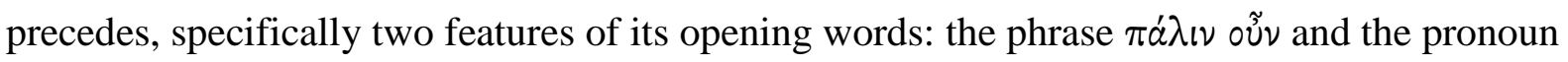

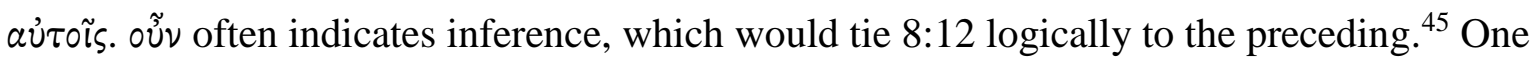
could argue that oũv holds too much semantic flexibility and could mean little more than "then," particularly in John where it occurs most frequently. In any case, it suggests continuation. The proposed link with the dispute concerning Jesus at the end of Chapter 7

\footnotetext{
${ }^{40}$ Udo Schnelle, Das Evangelium nach Johannes (3rd ed.; THKNT 4; Leipzig: Evangelische Verlagsanstalt, 2004) 170-171.

${ }^{41}$ Folker Siegert, Das Evangelium des Johannes in seiner ursprünglichen Gestalt: Wiederherstellung und Kommentar (SIJD 7; Göttingen: Vandenhoeck \& Ruprecht, 2008) 385-386.

${ }^{42}$ Herman C. Waetjen, The Gospel of the Beloved Disciple: A Work in Two Editions (New York: T \& T
} Clark, 2005) 234-237.

${ }^{43}$ Brooke Foss Westcott, The Gospel according to St. John (New introduction by Adam Fox; London: James Clarke \& Co., 1958) 128.

${ }^{44}$ Witherington, John's Wisdom: A Commentary on the Fourth Gospel, 174-175.

${ }^{45}$ Notably, Westcott, who unlike many others, draws attention to the presence of oṽv and suggests that it should be rendered "therefore," can only explain the link between 8:12 and 7:52 by saying, "The opinions about Jesus were divided. The rulers were blinded by their prejudices. Jesus therefore traces back doubt and unbelief to want of inner sympathy with Himself," Westcott, The Gospel according to St. John, 127, bold type in original. 
also accounts for aủ Jesus has already been addressing as he again ( $\pi \dot{\alpha} \lambda \iota \nu)$ speaks to them, or perhaps, though less likely, back to the Фapıraĩo $(7: 45,47,48)$ consulting together at the end of Chapter 7 and explicitly mentioned again in 8:13.

Nevertheless, many commentators do not mention any connection between 8:12 and the objection to Jesus' having come from Galilee at the end of Chapter 7, including Barrett, ${ }^{46}$ Bauer, ${ }^{47}$ Beasley-Murray, ${ }^{48}$ Bernard,${ }^{49}$ Brodie,${ }^{50}$ Brown,${ }^{51}$ Bruce,${ }^{52}$ Bultmann, ${ }^{53}$ Busse,${ }^{54}$ Carson, ${ }^{55}$ R. Alan Culpepper, ${ }^{56}$ Dodd,${ }^{57}$ Lightfoot, ${ }^{58}$ MacGregor, ${ }^{59}$ Sanders and Mastin, ${ }^{60}$

\footnotetext{
${ }^{46}$ Barrett, The Gospel according to St John, 335-338.

${ }^{47}$ Bauer, Johannes, 87.

${ }^{48}$ Beasley-Murray, John, 126-129.

${ }^{49}$ Bernard, A Critical and Exegetical Commentary on the Gospel according to St. John, 291-293.

${ }^{50}$ Brodie, The Gospel according to John, 323-324.

${ }^{51}$ Brown, The Gospel according to John (i-xii), 340, 343-344.

${ }^{52}$ Bruce, The Gospel of John, 188.

${ }^{53}$ Bultmann, Das Evangelium des Johannes, 260-261.

${ }^{54}$ Busse, Das Johannesevangelium, 164.

${ }^{55}$ Carson, The Gospel according to John, 337-339.

${ }^{56}$ R. Alan Culpepper, Anatomy of the Fourth Gospel: A Study in Literary Design (FF; Philadelphia:
} Fortress Press, 1983), references to 8:12 on 93, 109, 191.

${ }^{57}$ Dodd, Historical Tradition in the Fourth Gospel, references to 8:12 on 54, 130, 185, 317, 375, 377.

${ }^{58}$ Lightfoot, St. John's Gospel: A Commentary, 189.

${ }^{59}$ MacGregor, The Gospel of John, 192-194.

${ }^{60}$ Sanders and Mastin, A Commentary on the Gospel according to St John, 218-219. 
Morris ${ }^{61}$ Schnelle, ${ }^{62}$ Siegert, ${ }^{63}$ Waetjen,${ }^{64}$ Westcott,${ }^{65}$ and Witherington. ${ }^{66}$ By not recognizing the allusion and how it accounts for the placement of 8:12, many place a break before 8:12, severing the logical connection with what precedes, ${ }^{67}$ and some find difficulty explaining the position of 8:12. Waetjen calls 8:12 "an awkward transition from 7:45-52." ${ }^{68}$ Bultmann and Siegert see so little connection with the preceding that they place 8:12 after 9:41 and follow it with 12:44b-50, the latter stating that $\pi \alpha \dot{\lambda} \iota \nu$ in 8:12 "macht den Eindruck einer Verlegenheit und hat wohl etwas ursprünglich Passenderes ersetzen müssen." ${ }^{99}$

However, the allusion may play a greater role in John than merely a simple defense demonstrating that Jesus was not disqualified by coming from Galilee; it undermines his opponents at their very point of pride and affirms the testimony of the Scriptures to Jesus. Earlier in John 7, some members of the divided crowd voice the same objection to Jesus from

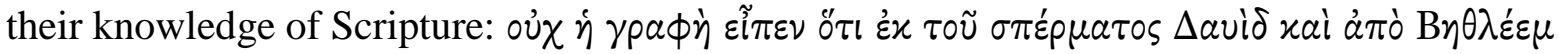

\footnotetext{
${ }^{61}$ Morris, The Gospel according to John, 436-439.

${ }^{62}$ Schnelle, Das Evangelium nach Johannes, 170-171.

${ }^{63}$ Siegert, Das Evangelium des Johannes in seiner ursprünglichen Gestalt, 385-386.

${ }^{64}$ Waetjen, The Gospel of the Beloved Disciple, 234-237.

${ }^{65}$ Westcott, The Gospel according to St. John, 128.
}

${ }^{66}$ Witherington, John's Wisdom, 174-175. Also Benjamin E. Reynolds, The Apocalyptic Son of Man in the Gospel of John (WUNT 2/249; Tübingen: Mohr Siebeck, 2008) 163-164, although understanding 8:12 and what follows as a continuation of discussion of the origin and identity of Jesus in Chapter 7, does not suggest any more specific link.

${ }^{67}$ E.g., Bruce, The Gospel of John, 25; Moloney, The Gospel of John, 251; and Sanders and Mastin, A Commentary on the Gospel according to St John, 218. G.H.C. MacGregor, The Gospel of John (MNTC; London: Hodder and Stoughton, 1928) 192-193 sees so little connection between 8:12 and what follows to the end of chapter 7 that he places it after 7:24. Contrast Barrett, The Gospel according to St John, 335: "The discourse is continued from 7.52. There is no indication of a change of place, and 8.20 shows that Jesus is still in the Temple (as at 7.28); but in these central discourses John seems indifferent to details of sequence and movement." Although Hartwig Thyen, Das Johannesevangelium (HNT 6; Tübingen: Mohr Siebeck, 2005) 419421 places a significant break before 8:12, he also notes the logical connection I am proposing on 423.

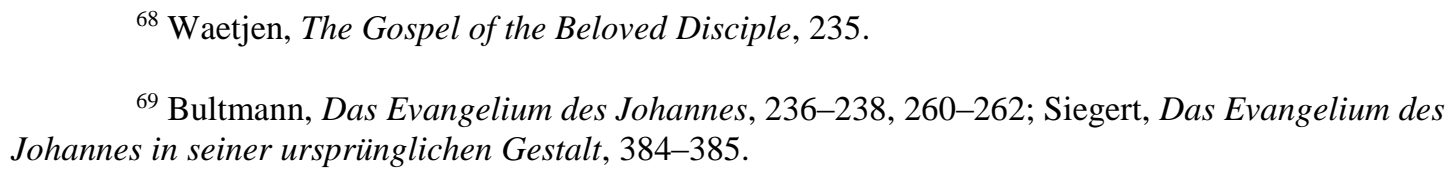




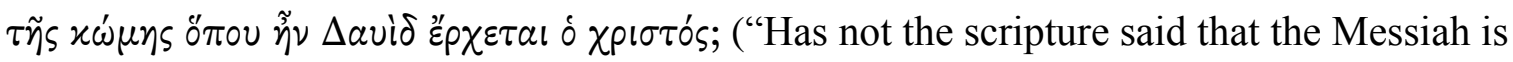
descended from David and comes from Bethlehem, the village where David lived?", 7:42). Yet when those sent to arrest Jesus return to the chief priests and Pharisees in amazement at

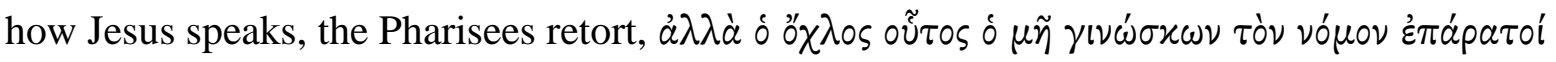

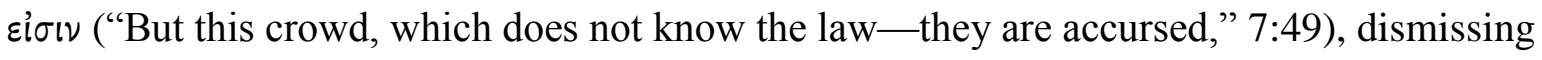
the foolish crowd as accursed and ignorant of the Law. When Nicodemus appeals to the Law to give Jesus a fair hearing, the other Pharisees do not flatly state that coming from Galilee

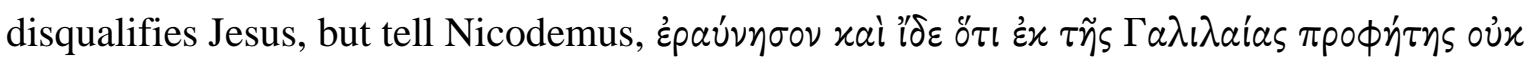

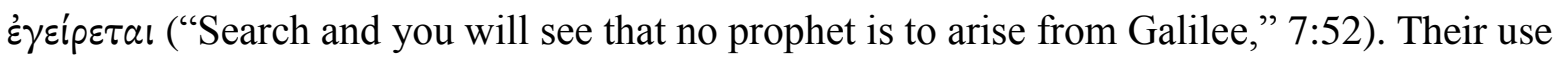

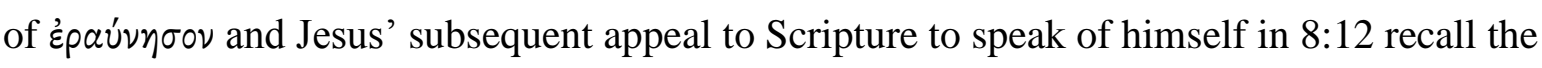
only other occurrence of épauváw in John.

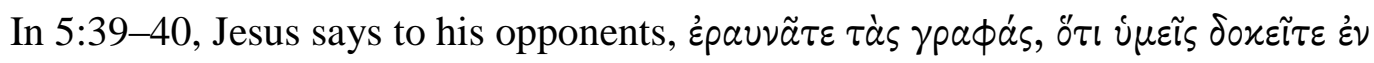

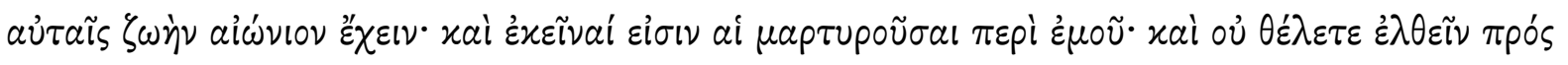
$\mu \varepsilon$ i้ $\alpha \zeta \omega \eta \dot{\nu} \nu$ है $\chi \eta \tau \varepsilon$ ("You search the scriptures because you think that in them you have eternal life; and it is these that testify on my behalf. Yet you refuse to come to me to have life"). A series of similarities between these two passages suggest a deliberate link. In Chapter 5, Jesus speaks of searching by the 'Iovঠaĩo in Jerusalem who are seeking to kill him (5:16). In Chapters 7 and 8, Jesus' opponents again seek to kill him $(7: 1,19 ; 8: 37,40)$ and tell one of their own to search. The object of search in both passages should properly be the Scriptures,

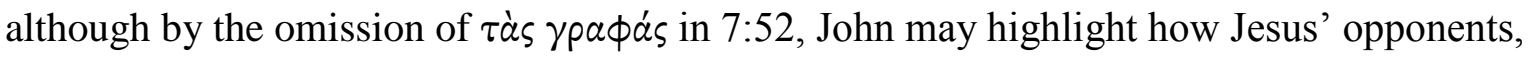
even as they condemn the crowd for ignorance of Scripture, overlook it themselves. In both passages, Jesus' opponents have failed to see how the Scriptures speak of him. In both, the

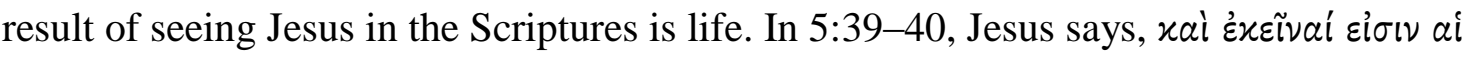

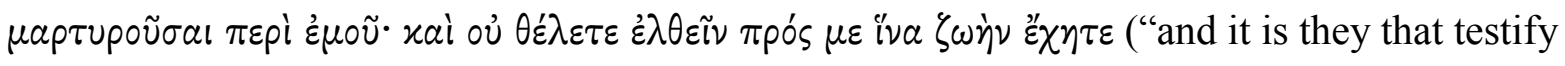


on my behalf. Yet you refuse to come to me to have life"). In 8:12, Jesus affirms that those who follow him $\varepsilon^{\prime \xi} \xi \varepsilon$ tò $\phi \tilde{\omega} \varsigma \tau \tilde{\eta} \varsigma \zeta \omega \tilde{\eta} \varsigma$ ("will have the light of life"). Additionally, the most recent occurrence of $\phi \tilde{\omega} \varsigma$ in John prior to 8:12 is in 5:35. Although $\phi \tilde{\omega} \varsigma$ speaks of John the Baptist in the earlier verse, it may further link the two passages. This link likely explains the insertion of an explicit mention of Scripture in 7:52 in Codex Bezae and Codex Washingtonianus, as well as the Old Latin, Clementine Vulgate, Sahidic, and Lycopolitanic..$^{70}$ Thus, by the allusion in 8:12, Jesus not only ripostes an objection, he undermines his opponents by revealing that they know the Scriptures even less than the crowd they condemn and reaffirms that the Scriptures speak of him. It continues the theme of testimony to Jesus from the Scriptures established by the many allusions to the OT in John and explicitly in $2: 22 ; 5: 39$, etc. Several commentators note the use of épauváw in the two passages but without noting all of these parallels nor perceiving how this recollection of John 5 further undermines Jesus' opponents through the allusion in 8:12. ${ }^{71}$ Lindars notes the link to 5:39 in light of the allusion to Isaiah but does not provide further support for it or develop it beyond

${ }^{70}$ See Aland et al., Novum Testamentum Graece, 322 and The American and British Committees of the International Greek Testament Project, The New Testament in Greek IV: The Gospel according to St. John, vol. 2, The Majuscules (ed. U.B. Schmid, W.J. Elliott, and D.C. Parker; New Testament Tools, Studies and Documents 37; Leiden: Brill, 2007) 335.

${ }^{71}$ Barrett, The Gospel according to St John, 332; Bernard, A Critical and Exegetical Commentary on the Gospel according to St. John, 290; Brodie, The Gospel according to John, 322; Bultmann, Das Evangelium des Johannes, 235, 235n5, implicitly Sanders and Mastin, A Commentary on the Gospel according to St John, 218. As mentioned above, Thyen notes both very briefly in Das Johannesevangelium, 422-423. Bauer notes the use of the word in 5:39 but dismisses a link from 7:52 back to it since the Scriptures mentioned a prophet from Galilee in $2 \mathrm{Kgs} \mathrm{14:25}$ and since $2 \mathrm{Kgs}$ 10:23 LXX (4 Kgs 10:23) contains a similar phrase without reference to Scripture; Walter Bauer, Johannes, vol. 2 of Die Evangelien (HNT 2; Tübingen: J.C.B. Mohr (Paul Siebeck): 1912) 84. Others not noting any connection between 7:52 and 5:39 include Beasley-Murray, John, 121, although he explains the searching as specifically a searching of "the Scriptures"; Brown, The Gospel according to John (i-xii), 330; Bruce, The Gospel of John, 185-186; Busse, Das Johannesevangelium, 163-164; Köstenberger, John, 244; Lightfoot, St. John's Gospel, 185-186; Morris, The Gospel according to John, 434; Siegert, Das Evangelium des Johannes in seiner ursprünglichen Gestalt, 350; Waetjen, The Gospel of the Beloved Disciple, 233; Westcott, The Gospel according to St. John, 125; Witherington, John's Wisdom, 174. MacGregor, The Gospel of John, 210 may recognize the use of the word in the two passages without explicitly noting it since he inserts "the Scriptures" in parentheses after "Search" in his comments. Similarly Carson, John, 332 and Schnelle, Das Evangelium nach Johannes, 166 say that Nicodemus is told to search the Scriptures without referencing 5:39. 
the mere citation of 5:39 with the simple statement that "there is a deliberate irony, for John knows well that Jesus' Galilean origin is in accordance with the messianic prophecy of Isa. 9.1f." 72

One final question: inasmuch as Jesus makes a messianic claim in 8:12, what other significance may lie in the Pharisees' objection specifically to a prophet in 7:52? ${ }^{73}$ Without addressing what ideas concerning an eschatological prophet references to "the prophet" in John may reflect, a few observations concerning the designation "prophet" and its relation to "Christ" in John suggest a further layer of irony.

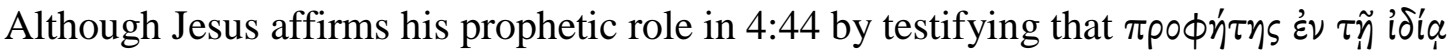

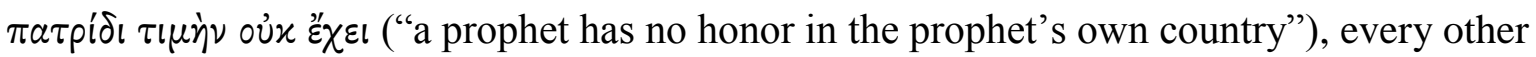
occurrence of the word in John appears in a context making a reference to the prophets of the past, distinguishing prophet from Messiah, or presenting the view of Jesus as prophet as inadequate or incomplete. Beginning from the most positive, 1:45 and 6:45 refer to "the prophets" in the plural to speak about what was written in Scripture. In the former, this explicitly concerns the Messiah. Similarly, identification of "Isaiah the prophet" precedes the quotation from Isa 40 in 1:23 and Isa 53 in 12:38. In the next category, 1:21 and 25

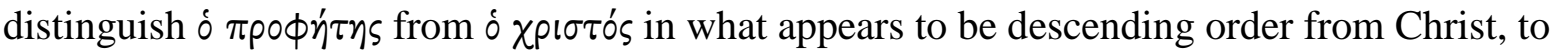
Elijah, to "the prophet." Similarly, 7:40 expresses the confusion of the crowd when some say

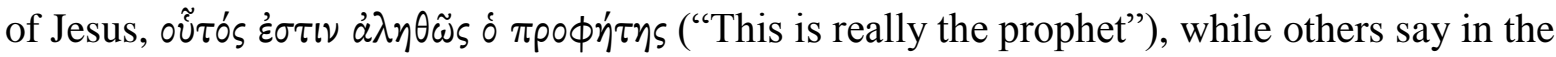

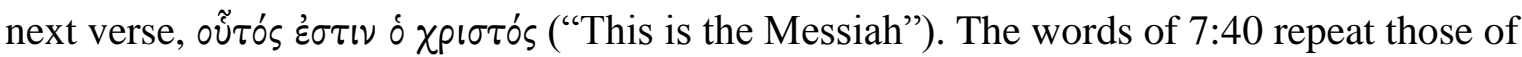
6:14, where the people, full of multiplied bread and fish, say in their inadequate

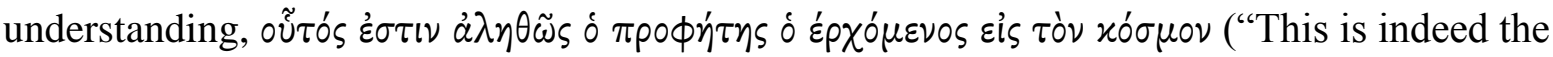

\footnotetext{
${ }^{72}$ Lindars, The Gospel of John, 305.

${ }^{73}$ The following discussion derives from conversation with Jamie Davies.
} 
prophet who is to come into the world"), only to have their efforts at coronation disappointed by the elusive Jesus, leading to offense and their abandonment of him by the end of the chapter.

Two passages in John that show a progression from inadequate, or incomplete, acknowledgement of Jesus as prophet to his claim to be Messiah deserve particular note. $\pi \rho \circ \eta^{\prime} \tau$ s occurs only one other time prior to 7:52 when the Samaritan woman, shocked by

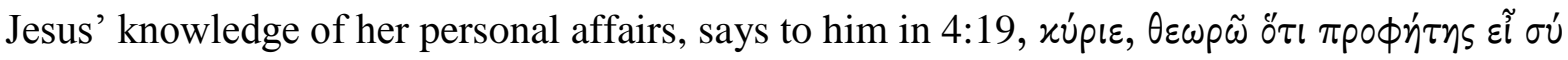
("Sir, I see that you are a prophet"). This occurrence of the word is particularly significant, since the passage identifies her acknowledgment of Jesus as prophet to be inadequate and shows him leading from it to his claim to be Messiah. When the woman goes on to speak of

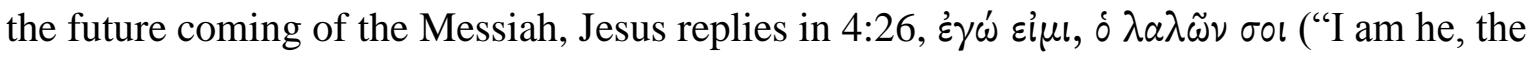
one who is speaking to you"). A similar progression appears in Chapter 9. When asked what

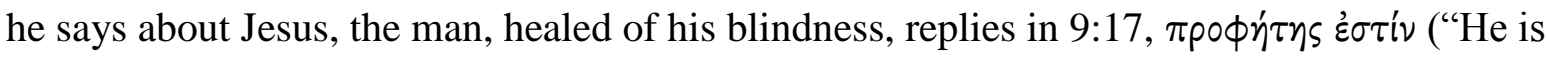
a prophet"). After continued debate about Jesus, in which the man reasons from saying he does not know whether or not Jesus is a sinner to saying that Jesus must be from God, and the

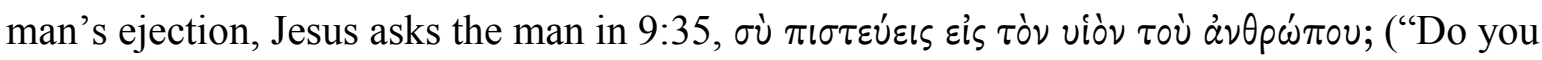
believe in the Son of Man?"). When the man asks who this Son of Man is, Jesus replies in

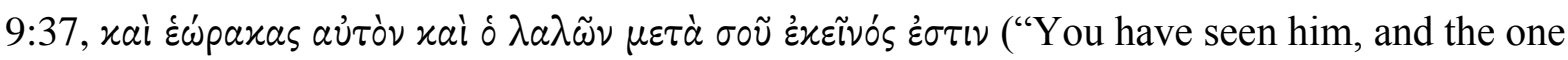
speaking with you is he"), leading to the man confessing belief and bowing before him.

When the Pharisees object to a prophet arising from Galilee in 7:52, they use an inadequate designation for Jesus in their rejection of him. ${ }^{74}$ They will not even allow that a

\footnotetext{
${ }^{74}$ Interestingly, the original hand of $\mathrm{P}^{66}$ included the article before $\pi \rho \circ \phi \eta \tau \eta s$ in 7:52. See The American and British Committees of the International Greek Testament Project, The New Testament in Greek IV: The Gospel according to St. John, vol. 1, The Papyri (ed. W.J. Elliott and D.C. Parker; New Testament Tools and Studies 20; Leiden: Brill, 1995) 231. This would make their objection specifically against Jesus as the figure mentioned in $1: 21,25 ; 7: 40$, and possibly $6: 14$.
} 
prophet comes from Galilee and, by inference, even less would they think the Messiah could come from there. Here again, ironically, they appear in a lesser light than the crowd they condemn. The crowds had at least questioned whether the Christ could come from Galilee on the basis of Scripture in 7:41-42. If yet a further layer of irony lies under 7:52 and 8:12, it may be that of the Pharisees entirely missing the point in their objection. They deny that Jesus is a prophet, but what he claims for himself is different from and higher than being a

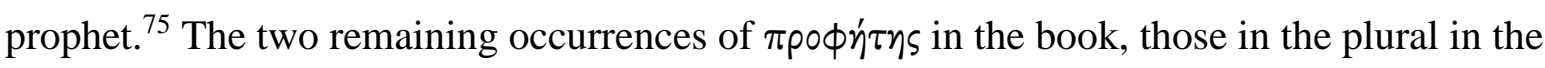
continuation of the conversation in 8:52 and 8:53, again present Jesus as greater than the prophets. Jesus' opponents question who he thinks he is in response to his claim that those

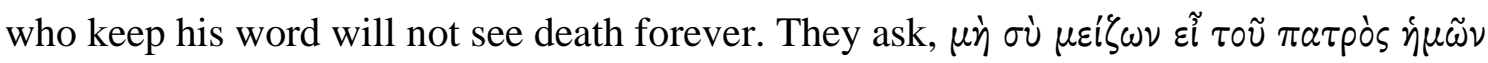

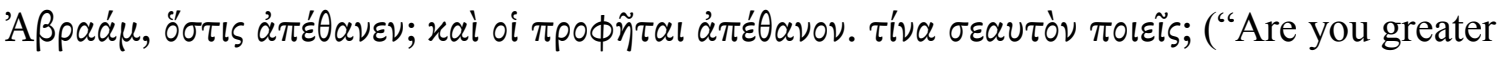
than our father Abraham, who died? The prophets also died. Who do you claim to be?"),

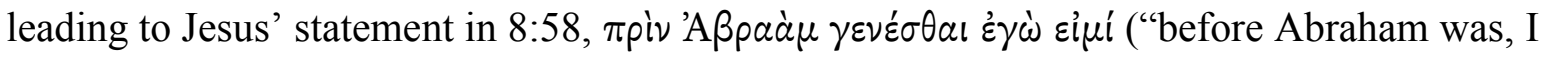
am").

\section{Conclusion}

Jesus' claim in John 8:12 to be the light of the world, according to my proposal, need not be awkwardly disconnected from what precedes. Nor do we need to seek for its primary significance by appealing to Qumran or gnostic literature with questionable parallels that may not even have been known to its audience, nor even to the use of lights during the Feast of Tabernacles. Rather, through a deliberate OT allusion, Jesus' claim affirms his own legitimacy by answering an objection of his opponents, reveals their failure to know the Scriptures in which they pride themselves, and unmasks their blindness to recognize him in the Scriptures. Yet the allusion also plays into the program of the book as a whole. By using

\footnotetext{
75 This was suggested to me by Jamie Davies.
} 
the language of Isa 8:23-9:1 and thereby recalling the messianic interpretation of the passage as it continues through Isa 9:6 to speak of a coming son who would sit perpetually on David's throne and be called Wonderful Counselor, Mighty God, Everlasting Father, and Prince of Peace, Jesus makes the startling claim about himself repeated throughout John. To combine the book's statement of purpose with Jesus' words in 8:12, the Christ, the Son of God, is Jesus, and the one who follows him will not walk in darkness but will have the light of life. Why? Because he is the light of the world who has come from Galilee. 